\title{
Diversity Matters: Immigrant Entrepreneurship and Contribution of Different Forms of Social Integration in Economic Performance of Cities
}

\author{
AYDA ERAYDIN*, TUNA TASAN-KOK** \& JAN VRANKEN ${ }^{\dagger}$ \\ *Department of Urban and Regional Planning, Middle East Technical University, Ankara, Turkey, \\ **OTB Research Institute for Housing, Urban and Mobility Studies, Delft University of Technology, \\ The Netherlands, ${ }^{\dagger} \mathrm{OASeS}$ Research Group on Social Exclusion, Poverty and the City, University of Antwerp, \\ Antwerp, Belgium
}

(Received July 2009; accepted September 2009)

\begin{abstract}
While it is quite common in studies of diversity to focus on its negative aspects, this paper specifically aims to emphasize the contribution of immigrants to the urban economic performance. By exploring different kinds of social integration, this paper discusses how immigrant groups can be important agents of urban economic growth and competitiveness by liberating creative forces and enhancing the competitiveness. Immigrant entrepreneurship is defined as the most important means of social inclusion and sustained economic performance in two different cities, with different features yet hosting considerable number of immigrants with diverse characteristics, namely Antwerp (Belgium) and Izmir (Turkey). The findings of our two case studies reveal that different kinds of diversity play an important role in urban economic performance. Immigrants contribute to the growth of different forms of production and services, not only because of their talents and skills, but also because of their social connections. Social capital enables immigrants to survive in a recipient country, and integrate into an economy as active agents. They can fill the gaps in an economy as entrepreneurs or the skilled labour, which are the most important assets for the cities aiming sustained economic growth in volatile economic conditions.
\end{abstract}

\section{Introduction}

Migration clearly affects cities in a multitude of social, economic, cultural and spatial ways. Due to their diverse populations, cities that attract migrants ${ }^{1}$ are multicultural and have distinct characteristics. How do forms of immigrant entrepreneurship contribute to urban social cohesion and economic performance of urban areas, and to what extent urban

Correspondence Address: Tuna Tasan-Kok, OTB Research Institute for Housing, Urban and Mobility Studies, Delft University of Technology, Jaffalaan 9, 2628 BX, Delft, The Netherlands. Email: m.t.tasan-kok@tudelft.nl 
communities benefit from this diversity? By exploring different kinds of social integration, this paper discusses how immigrant groups can be important agents of urban economic growth. In doing so, we aim to show that it is the key characteristics, or indeed the nature, of the diversity that matters, rather than ethnic or cultural differences. We start from the assumption that different kinds of diversity—ethnic, social and cultural—can contribute to urban economic performance, function as liberating creative forces, bring more social cohesion to cities and neighbourhoods and generally improve the quality of life in cities.

Our studies of Antwerp, a historically multicultural Flemish city that is home to diverse international immigrant groups (in terms of their ethnic, religious, cultural, social and economic characteristics) and Izmir, a Turkish city that also has a history of foreign and local migration, aim to show that immigrants follow different channels and processes when integrating into a new society. Despite the differences of the origin of the immigrants (international versus local), both groups had similar motivations to immigrate (for better economic conditions). Thus, experiences of these two different cities with immigrants actually help us to understand the possible positive contributions of social, cultural and ethnic diversity in urban society and economy out of the general context of ethnic migration. In both cases, diversity plays a crucial role in the general social cohesion and economic performance of the cities. However, this kind of comparison may hinder common conclusions as we actually do not compare the migration processes in these cities but compare the outcomes of migration.

In our discussion of the different aspects of social integration, we focus first on immigrant entrepreneurship; second, on the capacity and social capital of immigrants and finally, on informal social relations and support mechanisms. We emphasize the fact that immigrants can contribute to the creativeness and competitiveness of cities.

Immigrant entrepreneurship is a form of inclusion, as it increases interdependence and participation. In the case of Antwerp, immigrant groups have historically concentrated in particular areas. Over time, however, their businesses have spread throughout the city, as they have become more entrepreneurial and better integrated (Tasan-Kok \& Vranken, 2008). Integration via entrepreneurship thereby seems to have made a positive contribution to the city's general social cohesion, as the amount of interaction between diverse groups has increased. Moreover, Antwerp demonstrates that immigrant entrepreneurship not only contributes to the processes of urban social integration by increasing interaction between groups, but also brings innovations into businesses. Here, from a business point of view, immigrants' innovations can be seen as breaking through existing patterns of production and productivity (Nijkamp, 2003). Diversity, an important factor in urban economic performance, is reflected in cities' social capacities. The Izmir study, meanwhile, shows that, as in many metropolitan areas across the world, Izmir has a diversified social structure and labour market characteristics. Such diversity is not based on "ethnicity", however, as the literature suggests. Rather, it is grounded in cultural differences and different lifestyles, as defined by the residents' origins. When it comes to both social integration and adaptation, informal support mechanisms and social relations remain important determinants of success. Indeed, in both Antwerp and Izmir, the existence of family ties and friendship networks is the key factor underlying immigrants' social and economic success.

The paper is structured around a number of arguments that underscore the importance of diversity for economic growth and competitiveness. Following this introduction, in Section 2, we offer a critique of the dominant theoretical discourse. In Section 3, we 
explain our methodology, data collection and arguments. In Section 4, we outline different forms of immigrant integration into the local economies of Antwerp and Izmir. In Section 5, we explain how diverse backgrounds and socio-economic conditions can provide a number of positive reasons to promote integration, and outline the empirical evidence for the three main arguments developed in the study. Finally, the paper ends with a discussion of the issues raised.

\section{The Theoretical Discourse on Diversity: from Negative to Positive?}

As the city has never been a homogenous entity, social, cultural and ethnic forms of diversity have always been key items on the urban research agenda (Amin \& Graham, 1997). Indeed, Amin and Graham (1997, p. 418) define the contemporary city as "a variegated and multiplex entity - a juxtaposition of contradictions and diversities, the theatre of life. The literature imparts a clear message: diversity is the essential characteristic of the cities of the past, the present and (most probably) of the future. This diversity has assumed a very new dimension over the last couple of decades. As a result of processes of globalisation, neoliberalisation and economic restructuring, most urban centres in advanced economies have faced significant increases in migration. At the same time, doubts have been expressed about migrants" contributions to their host societies and to urban economies. Indeed, immigrants often have little opportunity to participate actively in urban economies, due to low skills levels, language deficiencies, cultural gaps and stigmatization (Nijkamp, 2003, p. 402). Moreover, issues such as social integration, exclusion, crime, racism and discrimination have been very much at the centre of political, public and research debates.

Gradually, however, a number of studies have begun to identify how immigrants can make a positive contribution to the socio-economic well-being of neighbourhoods and cities. Recently, concerns have been increasingly expressed about the social benefits of multiculturalism. From an economic perspective, meanwhile, debates about diversity have recently entered the competitiveness literature (Thrift \& Olds, 1996; Storper, 1997; Florida, 2005). This shift is connected to the increasing emphasis in contemporary European social and economic policies on the discourse of "competitiveness and cohesion", thereby transforming a "capital-labour" relations issue into a technical-administrative issue, and both de-politicizing and de-socializing it (Maloutas et al., 2008). Within this framework, economic competitiveness seems to be a prerequisite for developing social cohesion. A lack of cohesion, meanwhile, is considered to be detrimental to economic development. However, it is difficult to empirically prove the extent to which social cohesion increases economic competitiveness, or vice versa. Fainstein argues that "the competitive advantage of cities, and thus the most promising approach to attaining economic success, lies in enhancing diversity within the society, economic base, and built environment" (Fainstein, 2005, p. 4). In the same vein, Zachary states that openness to immigration is a key factor for economic growth (Zachary, 2000; see also Florida, 2001, p. 91). This argument is supported by many others, including Bodaar and Rath, who claim that "city boosters increasingly acknowledge that urban diversity is a vital resource for the prosperity of cities and a potential catalyst for socio-economic development" (Bodaar \& Rath, 2005, p. 5). These arguments highlight how diversity can play a positive instrumental role in achieving a creative and competitive economy.

Another important positive perspective on diversity is related to its role in fostering creativity and innovation. It is widely thought that factors such as social capital, creativity and 
innovation can play crucial roles in urban economic growth (Landry, 2000; Florida, 2001; Fainstein, 2005). It is important to recognize that creativity has many faces, and plays both a direct and indirect role in economic development. Clearly, then, creativity should be stimulated (Tasan-Kok \& Vranken, 2008). Kunzmann (2005, p. 7) argues, meanwhile, that educated people are not solely responsible for fostering creativity. Rather, a diverse range of people and activities can offer creative input and generate innovative ideas. In this respect, immigrants also make a contribution to the creative life of cities.

Indeed, in the migration literature, there is growing interest in the positive contribution that immigrant entrepreneurs can make to social cohesion and economic competitiveness (Waldinger et al., 1990; Waldinger, 1997; Rath, 2000; Barett et al., 2001; Kloosterman \& Rath, 2001; Ratcliffe, 2001). Kloosterman and Van der Leun (1999), for instance, point out that the phenomenon of immigrant entrepreneurship offers neighbourhoods a winwin situation, creating job opportunities and making neighbourhoods more attractive. Positive approaches have also been taken in the literature with respect to the role of and sectoral contributions made by immigrant entrepreneurs in post-industrial and serviceoriented urban societies (Zachary, 2000; Rath, 2001; Sandercock, 2003; Uitermark et al., 2005), and in social integration processes via social innovation (Mumford, 2002; Gerometta et al., 2005; Gonzáles \& Healey, 2005). However, this does not mean that everything is so positive and smooth. In the early stages of the immigration, entrepreneurship was seen by immigrants as a way to prevent the obstacles of exclusion from the formal labour market and being in an unfamiliar environment. They were motivated to be creative to find the ways to survive in the market. However, it has soon become a common knowledge that especially second-generation young boys are not interested in working or running their own businesses. Although changed in recent years, the welfarist policies let them to survive in the society without being too creative to find/create job opportunities. This constitutes an important obstacle for the immigrant communities for their upward social mobility in the urban society.

Most debates on economic competitiveness refer to social capital, linking the latter with creativity and innovation as factors that stimulate urban economic growth (Landry, 2000; Florida, 2001, 2005; Fainstein, 2005). To be sure, forms of social, cultural, ethnic and spatial diversity attract multiple forms of human capital, and undoubtedly encourage cultural and artistic creativity, and technological and scientific innovation (Fainstein, 2005). Competitiveness, however, can be stimulated in different ways, with implications for how particular cities should integrate into the global economy. Owing to the fact that large numbers of cities (and other territorial units) are competing globally in terms of wages, integration into the global market can also be achieved using cheap immigrant labour. There is a wide literature on this type of integration and on the various ways of organizing (flexible) production, enabling cities and countries to become more competitive in labour-intensive sectors (Beneria \& Roldan, 1987; Benton, 1990; Chant \& McIlwaine, 1995; Peck, 1996; Eraydin \& Erendil, 1999).

From a societal perspective, the role of social capital has been emphasized in relation to social cohesion and diversity. According to Bourdieu, social capital is a resource or a power relation that agents achieve through building and maintaining social networks and connections (Bourdieu \& Wacquant, 1992, p. 119). Bourdieu's definition focuses on the actual network resources that are possessed by an individual or group. These resources help them to achieve a particular goal, such as finding employment or somewhere to live. Portes (1998), meanwhile, draws specifically on Bourdieu's definition of 
social capital in his discussion of immigration and the role of social capital. As a whole, the literature emphasizes how different forms of social capital are important for migrants, enabling them to survive in the new society.

According to the literature, the first type of social capital is the "bonding capital" that is created via the strong social ties that exist between individuals, family members, close friends and members of certain ethnic groups. Studies indicate that neighbourhoods with high levels of bonding social capital tend to be those in which low-income households can survive with the aid of kinship ties and ethnic solidarity (Forrest \& Kearns, 2001; Foord \& Ginsburg, 2004; Turok \& Bailey, 2004). A second type of social capital is "bridging capital"; the capital that is hidden in the weaker, cross-cutting social ties that exist between heterogeneous individuals, such as "friends of friends" or neighbours (Kleinhans et al., 2007). This form of social capital develops when migrants become part of a local economy and establish relationships with people other than their relatives, especially in their working lives (Forrest \& Kearns, 2001). A third type is "linking capital", which is characterized by connections between individuals, established professional and administrative structures, and local communities (Foord \& Ginsburg, 2004). This allows individuals to become involved in a city's decision-making mechanisms. In these ways, social capital can facilitate the integration of immigrants into a recipient society relatively quickly, and over time, enables them to become part of that society. However, the literature emphasizes that social capital must not be seen only as a positive asset; it can also have negative effects. Social capital can be positive when social networks are enabling, allowing immigrants to access (better) job opportunities, education and so forth. Social capital can be negative, however, when it is restraining individuals and when they are repressed by cultural norms and values because of the social control (Portes \& Sensenbrenner, 1993; Portes \& Landolt, 1996; Wall et al., 1998).

Informal social relations, social networks and supportive family relations can all play an important role in developing social capital. Pichler and Wallace (2007) argue that self-help and family help can compensate for the absence of welfare provisions. In the case of immigrant communities, meanwhile, social relationships can function as a compensation mechanism for processes of social integration. Pichler and Wallace argue that social support mechanisms offer a concrete indication of the strength of informal social capital. By this, they mean the extent to which people give or provide different kinds of services within informal networks (Pichler \& Wallace, 2007).

Very few comprehensive studies explore diversity from the perspective of economic competitiveness. Moreover, the existing literature tends to assess the consequences of immigration from a particular point of view, namely either that of the immigrant (how difficult it is to integrate) or of the host country (the challenges posed by the issue and the multi-levelled policy responses that are needed). By contrast, we approach diversity from a different perspective: one that underlines the positive aspects of diversity for greater social integration and urban economic competitiveness.

\section{Research Methodology and Hypotheses}

Bearing these theoretical discussions in mind, and with a view to the multicultural realities of Izmir and Antwerp, we developed three hypotheses in this paper: (1) immigrant entrepreneurship is a form of inclusion, as it increases interdependence and participation; (2) immigrants' skills and talents not only increase their chances of integrating 
successfully, but also contribute to a city's economic performance; (3) informal support mechanisms remain critically important not only for social integration, but also for the economic success of migrants and their localities. For the first hypothesis assumption, Antwerp is used as a case study, and the second one is tackled in Izmir. The third assumption connected Izmir and Antwerp and checked in both cases. For the first two assumptions, there was not a representative sample due to the different nature of the available data.

The first hypothesis touches two aspects of immigrant entrepreneurship. First, entrepreneurship changes the characteristics of and increases the level of interaction between immigrants and existing residents. Second, the level of immigrant participation in society increases with entrepreneurship, as immigrants move to new business areas that are unconnected with ethnic origin. In other words, immigrants use their networks and skills to advance their entrepreneurship.

In order to ascertain the validity of these two claims, we undertook qualitative research involving Turkish immigrants in Antwerp. We conducted a three-stage field survey between December 2006 and February 2007. During the first stage, we created a database by scanning the website of Antwerp's Kruispuntbank van Ondernemingen (Database of Entrepreneurs, or KBO) to identify Turkish-owned businesses. The KBO not only displays a Turkish business's year of establishment, type and location, but also its history. Thus, we could track whether the business owner had previously owned a business, and whether the nature of the business had changed over time. Unfortunately, the database allowed us to search on the basis of only names and postcodes. To ensure that we had covered a substantial number of entrepreneurs, we hired a native Turkish-speaking student to scan the Antwerp Business Guide (Yellow Pages) to find Turkish businesses that could not be identified via the KBO database. As a result, our database consisted of 319 Turkish businesses, and we knew the business history in central Antwerp districts for 228 of these. During the second stage of the fieldwork, we selected businesses from the database according to their Turkish origins, and conducted a total of 50 telephone interviews $^{2}$ in Turkish (conducted by the native Turkish speaking student). During the final stage of the research, we conducted 15 face-to-face narrative interviews (in Turkish) with entrepreneurs whose businesses we had identified as innovative (as they developed original ideas which are copied rapidly by the other Turkish entrepreneurs) at the city level, in terms of their business strategies and type of new speacialization areas within service. Turkish entrepreneurs, having a couple of decades of experience, noticed that staying in the same neighbourhood and serving the same clientele would not lead to a long-term benefit (Tasan-Kok \& Vranken, 2008). They adopted new business strategies to reach native population and located their business out of Turkish business and residential concentration areas. They have also followed new trends in sectoral choice and in the services where innovativeness is more important. We asked the entrepreneurs the motivations for the innovations, for the selection of the location, services and products; as well as their experiences during the process of the development of their businesses.

As we will explain in the sections below, this field survey allowed us to show that the spatial dispersal of Turkish businesses into non-immigrant neighbourhoods has indeed led to increasing interaction between Turkish immigrants and native Belgians. Second, based on the field survey, we could show that Turkish businesses are not only selling ethnic products to fellow citizens, but have also become innovative and competitive in the wider market. 
Our second hypothesis has two components: first, we argue that the development of new types of activities is dependent not only upon the existence of skilled labour, but also on access to a mature manufacturing sector that allows for an increased export capacity and new employment opportunities - areas in which immigrant labour play important roles. Second, we claim that immigrants can make a positive contribution to the cohesion of a city as a whole, on the grounds that they have a high degree of connectedness at various levels (individual, family and neighbourhood), which is thought to be a key factor in stimulating economic competitiveness (Fainstein, 2005).

In order to ascertain the validity of these two arguments, we undertook a quantitative field survey in Izmir. This survey covered 496 Izmir households, and aimed to identify differences between people from Izmir and immigrants from other parts of Turkey and abroad. The survey focused on factors such as education and occupation, as well as social relations. In order to define the sample, we first analysed the socio-economic geography of Izmir, taking neighbourhoods as our units of analysis. The findings of this analysis revealed differences among people from different neighbourhoods in terms of education, occupation and unemployment levels, all of which were important for identifying the main characteristics of the neighbourhoods. These neighbourhoods were then categorized into eight different types, based on the three factors mentioned earlier, and one neighbourhood was selected from each category. Second, prior to conducting the questionnaire, each of these neighbourhoods was visited and in-depth pilot interviews were conducted with neighbourhood heads (muhtar) and locals in order to establish whether our categorization had been appropriate. Third, we produced a questionnaire that focused on changes to respondents' income levels and quality of life (both Izmir-born residents and immigrants), patterns of interaction, survival strategies, responses to changing conditions and so forth. In total, 496 questionnaires were distributed between June and July $2007 .^{3}$

For the third hypothesis, we focused on the different types of informal support mechanisms that are developed via informal social relations. This argument connects Izmir and Antwerp with respect to the characteristics that their immigrants hold in common: informal social relations and social capital. As far as Izmir is concerned, the evidence suggests dependency on traditional, family-based support mechanisms. In Izmir, one of the key points to emerge from the interviews was related to the social capital and levels of social connectedness achieved by different social groups and migrants arriving from other regions and from abroad. In the case of Antwerp, meanwhile, we explored the financial support mechanisms and choices available to small entrepreneurs.

\section{Immigrants in Antwerp and Izmir: Different Forms and Conditions of Integration into the Local Economy}

The ways in which immigrants become integrated into socio-spatial structures vary considerably, depending on factors such as background, level of education and skills, an immigrant's social relations, motivation and the opportunities that a particular city might offer. The complexity of this situation demands that we need to examine immigrants' characteristics and assets, as well as what they can offer to their new socioeconomic environments.

An analysis of migrants' characteristics thus constitutes one important dimension of this group's contribution to competitiveness-seeking cities in an era of globalization. The literature highlights several points as far as the impact of economic growth on 
labour markets is concerned. First, integration into the global economy may depend on having different competitive assets, each creating demand for different types of labour. Second, the skills and occupational composition of the new labour market defines which groups will have access to new job opportunities. Third, the existence of unemployed people, a potential force in the labour market and different ways to recruit these people into new activities are important factors for economic growth (Turok, 2005). A review of the literature suggests that migrants with different levels of education and talents will be affected in different ways by these new conditions, and in turn, they may contribute in different ways to the local economy.

Antwerp is the second largest port in Europe, as well as being the most multicultural and vibrant Flemish city (certainly as far as ethnic, social, cultural, economic and spatial diversity is concerned). Owing to its port, trade and industry have always been the driving forces of Antwerp's economy. Historically, trade and port activities have significantly shaped the city's multicultural nature. Antwerp has always been a magnet for immigrants of all kinds, although the nature of migration has changed in line with economic, social and political changes at the national level. The city attracted merchants from many countries from the fifteenth century onwards, until the port of Rotterdam eclipsed Antwerp's activities in mid-sixteenth century. From the mid-nineteenth century onwards, the city regained its former economic status. Aided by French influence, the city developed its infrastructure, including new docks, which boosted the city's multicultural character. As far as diversity is concerned, however, the wave of immigration that the city has been experiencing since late 1960s has had the greatest impact. Since this time, there has been an influx of unskilled Turkish and Moroccan labour into the city. The most important characteristic of Antwerp, however, that gives the city its particular multicultural identity is that it attracts not only labour migrants, but also people of various ethnic, religious and cultural backgrounds. Turkish immigrants, who constitute the third largest immigrant community in the city, tend to come from less wealthy backgrounds, and have migrated to improve their economic conditions. The city hosts over 4000 Turkish residents, making up $0.88 \%$ of the total population and $7.5 \%$ of the total immigrant population in year 2004 .

At present, 17 different nationalities live in the city. Antwerp's immigrant community is very diverse, both in terms of individuals' motivations for immigration (whether they are unskilled workers, refugees, and so forth) and in terms of immigrants' religious and cultural backgrounds (the city is host to Orthodox Jews; Muslims from North Africa, the Balkan countries, Turkey and the Middle East; Hindus from India; and Christians from former colonies in Africa and from Eastern Europe, among others) (see Table 1).

As far as employment is concerned, immigrants are mainly employed at the low-end of the city's job market. In 2002, 8.2\% of wage-earners in the service sector were immigrants, while $11.2 \%$ of self-employed workers were of foreign origin (see Table 2). Moreover, in the same year, almost $30 \%$ of unemployed individuals in Antwerp were of foreign origin. It is generally thought that the existence of favourable social welfare provisions deters young immigrants from working, as unemployment benefits are rather high (a net payment of $€ 1000$ per month). The Belgian Government is working to change the benefits system, however, so as to focus on providing short-term support.

In 1989, immigrants made up $11 \%$ of the population of Antwerp; in 1999, this figure had reached 13\%, and in 2008, 14\% (Statistisch Jaarboek Antwerpen-Statistics of Yearbook of Antwerp). The increase of the immigrant population reflects the higher fertility rates among the immigrants and ongoing migration to the city. These figures do not accurately 
Table 1. Antwerp's population by origin (2004)

\begin{tabular}{lrc}
\hline Nationality & Population & Share in total $(\%)$ \\
\hline Total & 454,933 & 100 \\
Belgian & 402,246 & 88.4 \\
EU & 18,387 & 4.0 \\
Rest of Europe & 4681 & 1.0 \\
Moroccan & 11,791 & 2.6 \\
Turkish & 4182 & 0.9 \\
Rest of the world & 11,786 & 2.6 \\
Asylum seekers & 1860 & 0.4 \\
Total immigrants & 52,687 & 11.6 \\
Total non-EU immigrants $^{\text {a }}$ & 34,300 & 7.5 \\
\hline
\end{tabular}

${ }^{\text {a }}$ People who originally come from another country (either born there or born from parents who were born there). Source: Staat van de Stad, Databank Sociale Planning, 2004 (State of the City, Databank of the Social Planning Department of City of Antwerp, 2004).

Table 2. The employment situation of immigrants in Antwerp (2004)

\begin{tabular}{lcccc}
\hline & $\begin{array}{c}\text { Total in } \\
\text { Antwerp }\end{array}$ & $\begin{array}{c}\text { Share of immigrants in } \\
\text { total }(\%)\end{array}$ & $\begin{array}{c}\text { Share of non-EU } \\
\text { immigrants }(\%)\end{array}$ & $\begin{array}{c}\text { Total } \\
(\%)\end{array}$ \\
\hline Wage-earners & 138,920 & 8.2 & 4.6 & 75 \\
Self-employed & 22,995 & 11.5 & 4.1 & 12 \\
Unemployed & 30,435 & 29.7 & 25.5 & 12.6 \\
\hline
\end{tabular}

Source: Staat van de Stad, Databank Sociale Planning, 2004 (State of the City, Databank of the Social Planning Department of City of Antwerp, 2004).

reflect the presence of "ethnic minorities", however, for three reasons. First, a significant number of foreigners have used a recent and liberal naturalization procedure to become Belgian; second, Antwerp has a very large population of "undocumented people" and third, the presence of second- and third-generation migrants.

Turkish migration started in 1963, when Belgium began to look for new sources of recruitment for low-skilled and cheap labour. There was a particular need for labourers to work in the coal mines, after the Italians, with whom mining work in Belgium had been popular, began to lose interest due to their upwards social mobility (Kesteloot et al., 1997). As a result, the first wave of immigrants flowed mainly to the mining areas in Wallonia, while the second wave settled in Ghent (textile industry), Brussels and Antwerp (construction and services) (Kesteloot et al., 1997). Turkish immigrants, who were mainly from rural regions (specifically from villages surrounding a small middleAnatolian town, Emirdağ), arrived in Antwerp in a form of chain migration. Family networks are thus very important to these immigrant workers, as are associations of all sorts: cafés, shops and mosques. As a result, the Turkish community is relatively inwardlooking, and deliberately self-contained. Turkish immigrants tend to concentrate in particular neighbourhoods, mainly in the south-western and north-eastern parts of the city. As far as employment is concerned, problems with participating in the formal job market mean that most try to become self-employed, although not everyone is successful in this respect. 
Like Antwerp, Izmir is a vibrant port city, and one of the oldest cities in the Mediterranean Basin. From the seventeenth century onwards, Izmir earned its fame as one of the world's most important port cities. The city's population, which is composed of people of various origins (especially Greek, French, Italian, Dutch, Armenian, Sephardic and Jewish), transformed the city into a cosmopolitan trade portal during the second half of the nineteenth century. The internationally sanctioned exchange of population between Turkey and the Balkan states during 1912-1913 Balkan Wars, and the 1923 Treaty of Lausanne, which defined the exchange of nearly 2 million Greeks, ${ }^{4}$ some of which were from Izmir, for approximately 500,000 Muslims, who were forced to leave their homes in the Balkans, had a negative effect on the city's multicultural character after the First World War (Hirschon, 2003). In the 1950s, however, migration from different parts of Anatolia created a new kind of diversity, one that was not based on ethnic origin, religion or language, but on lifestyle, habit and cultural practices.

In the 1950s and 1960s, the city attracted immigrants from less-developed parts of Turkey. During the 1970s and 1980s, as well as the ongoing migration from poorer Turkish regions, the city received considerable numbers of people from the Balkan countries (including Bulgaria, former Yugoslavia and Macedonia), as well as returning migrants from Germany, some of whom had relatively high skill levels. In recent decades, it has become increasingly evident that the city is attracting many migrants from more advanced regions, and that these workers are better educated and more highly skilled. Migration therefore supplies the needs of new sectors that are seeking highly-qualified workers, as well as unskilled labour for employment in those traditional industries for which Izmir retains a comparative advantage; that is, agricultural productbased industries, textiles and other mature production sectors.

These immigrants, who have come to the city from all over Turkey and from abroad, have different backgrounds, living and working habits, social relations and differing future aspirations. According to the field survey results, of the 496 households surveyed, 184 reported that they had been born in Izmir (37.1\%), while $14.5 \%$ had migrated from nearby provinces and from the Aegean region. These two percentages indicate that half of the households in the sample consist of people with the same cultural background, which agrees with the figures produced by State Institute of Statistics (DIE). Those from the remaining population have migrated from different Turkish regions or from abroad. Our survey found that workers from abroad constituted $7.5 \%$ of our sample. As Table 3 shows, the largest group of migrants are those from Inner Anatolia and the southern and northern coastal regions of Turkey, which can be grouped together as middle-income regions (see Figure 1 for the regions in Turkey). ${ }^{5}$

The second largest group originates from the least-developed regions, which are to be found in the eastern and southern parts of Turkey. The city's share of immigrants from the high-income regions located around the Marmara Sea is also significant, amounting to almost $7 \%$ of the total population.

\section{The Contribution of Immigrants to Social Integration and Economic Performance}

Immigrants can make a positive contribution to a metropolitan city's competitiveness in a number of different ways. For the Antwerp case study, we analysed how ethnic entrepreneurship on the part of immigrants can make a positive contribution. In Izmir, 
Table 3. Household regions (NUTS I level) of origin, field survey sample (Izmir)

\begin{tabular}{lr}
\hline & $\%$ \\
\hline Izmir-born & \multicolumn{1}{c}{37.1} \\
Migrants from surrounding regions $^{\mathrm{a}}$ & 14.5 \\
Migrants from high-income regions $^{\mathrm{b}}$ & 6.9 \\
Migrants from medium-income regions $^{\mathrm{c}}$ & 21.1 \\
Migrants from least-developed regions $^{\mathrm{d}}$ & 12.9 \\
Migrants from abroad $^{\text {Total }}$ & 7.5 \\
\hline
\end{tabular}

${ }^{\mathrm{a}}$ TR3 Aegean.

'TR1 Istanbul, TR2 Western Marmara, TR4 Eastern Marmara, TR5 Western Anatolia.

${ }^{\mathrm{c}}$ TR6 Mediterranean, TR7 Middle Anatolia, TR8 Western Black Sea, TR9 Eastern Black Sea.

${ }^{\mathrm{d}}$ TRA Northeast Anatolia, TRB mid-Eastern Anatolia, TRC Southeast Anatolia. Source: Interviews, field survey, June-July 2007.

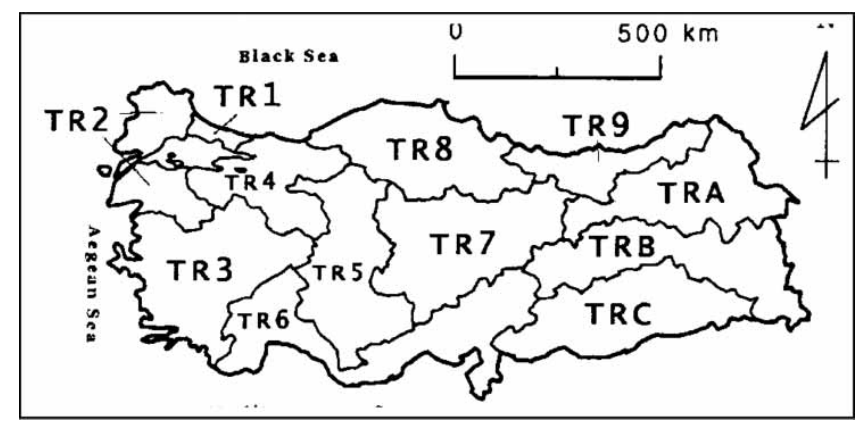

Figure 1. Regions (NUTS I level) in Turkey

Note: The figures on the maps denote the following regions. TR1 Istanbul, TR2 Western Marmara, TR3 Aegean, TR4 Eastern Marmara, TR5 Western Anatolia, TR6 Mediterranean, TR7 Middle Anatolia, TR8 Western Black Sea, TR9 Eastern Black Sea, TRA Northeast Anatolia, TRB MidEastern Anatolia, TRC Southeast Anatolia.

meanwhile, we focused on how social connectedness and labour characteristics can provide a means of social integration. Third, we focused on a factor common to both cities, which helps immigrants to integrate socially and achieve economic success: the presence of informal support mechanisms and networks.

\subsection{Immigrant Entrepreneurship as a Means of Social Integration in Antwerp}

Immigrant entrepreneurs make a positive contribution to Antwerp's social cohesion, in the sense that they create more interaction among diverse groups. As they become more specialized in businesses that are unrelated to their ethnic origins, immigrant entrepreneurs contribute to local economic development. 
According to the KBO (Kruispuntbank voor Ondernemingen-Crossroads Bank for Entrepreneurs) database of 2007, there are approximately 350 Turkish entrepreneurs in the City of Antwerp. It is difficult to know the exact number, however, as such data are not classified according to ethnic or religious identity. While it is easy to identify the neighbourhoods in which Turkish immigrants tend to cluster, due to the availability of residential data, such information is thus rather limited as far as businesses are concerned. Using the KBO database, however, we identified recent patterns in Turkish business locations. Over time, there has been a clear shift among Turkish businesses away from Turkish-dominated neighbourhoods, and a number of Antwerp neighbourhoods have profited from the establishment of immigrant businesses. In the central shopping streets such as Driekoningenstraat, Statielei and Brederodestraat, where Turkish and Moroccan businesses are mainly concentrated, one encounters a very colourful, dynamic neighbourhood atmosphere. Our face-to-face narrative interviews revealed that there has been high mobility in those streets in terms of businesses changing, shops closing and other forms of failure such as banckruptcy. Despite this, such streets are very popular among native Belgian residents.

Although our data from the business registers only date back to the early 1980s, we know that at the end of the 1960s and the 1970s, some Turkish businesses did exist in the city, although not in high numbers. The first generation of businesses consisted of small-scale enterprises that only served the immediate community's needs (language limitations prevented the first wave of immigrants from shopping elsewhere). These businesses were scattered along the earlier-mentioned streets and neighbourhoods, until the Turkish community became stronger and more involved in the city's economy.

The locational choices and behaviour of Turkish entrepreneurs have changed over time. In the course of our research, we discovered that those immigrants who are better integrated are also more sensitive to market demand. Drawing on a couple of decades of experience, these entrepreneurs realized that staying in the same neighbourhoods and serving the same clientele would not offer benefits in the long term. While our data do not allow us to identify how the establishment of businesses has changed over time, we do know that over the years, the share of Turkish businesses in each neighbourhood has changed.

Moreover, we discovered that immigrant businesses began to move out of those neighbourhoods in which Turkish immigrants are concentrated. Our findings suggest that while Turkish businesses still have a strong presence in Turkish neighbourhoods, there has also been a decentralization to other areas. Even though one can identify a few clusters in the centre of the city (especially in the south and south-west), the businesses are clearly dispersed throughout the city, even in neighbourhoods such as Deurne and Wilrijk, which are generally dominated by middle- and upper-middle-class Belgians. Interviews conducted with the first-generation Turkish immigrants confirmed that the first businesses did indeed cluster in those areas in which Turks first settled (mainly in the south of the city along the Brederodestraat, and scattered through Berchem and Borgerhout).

Although traditional locational patterns remain dominant, $11 \%$ of the entrepreneurs whom we interviewed indicated that they had chosen their location because they had noticed that a particular service was missing in an area, and hoped that they could be successful by providing it. A quarter of interviewees had already realized that it was necessary to be close to a core business area, such as the city centre or one of the main shopping streets. During the interviews, we discovered that some respondents are deliberately seeking particular locations in order to become more successful. One such interviewee 


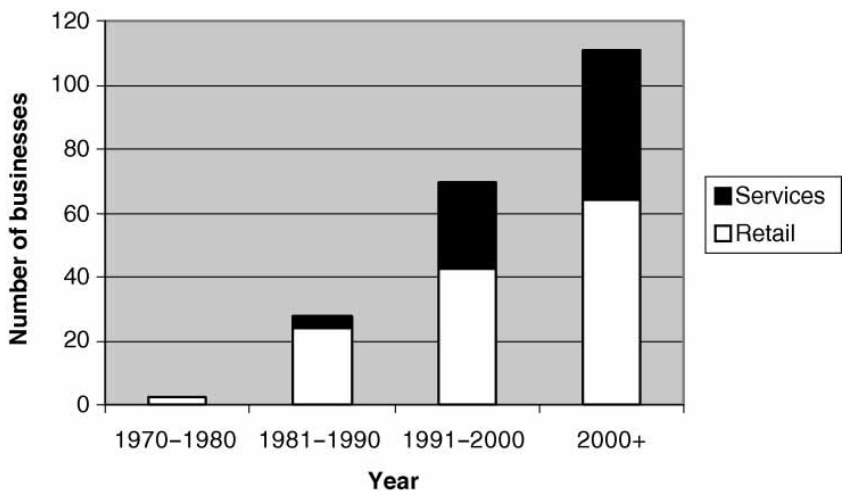

Figure 2. Share of retail and services in total KBO-registered businesses by year in Antwerp Source: Data gathered from Kruispuntbank van Ondernemingen (Database of Entrepreneurs, or KBO).

pointed out that he had selected Deurne as the location for his shoe shop, on the grounds that all of the other shoe shops in the area were selling expensive designer brands. By opening a store offering more reasonable prices, he expected to become popular in the neighbourhood, and he has now been running his business for over four years. Another interviewee, whose previous kebab shop had failed due to fierce competition, responded by moving to a more "Belgian" area where he faces much less competition.

Slowly but surely, all of these patterns of behaviour increase levels of interaction between diverse groups in neighbourhoods that had previously lacked any traditional Turkish businesses. Based on the KBO database, we were able to identify two main categories of business: services and retail. Traditionally, Turkish entrepreneurs have established smallscale retail activities, such as small-scale food and non-food stores, convenience stores, wholesalers and so forth. The term "services", meanwhile, covers a wide variety of businesses, such as organizational and cleaning services, construction and other smallscale business services. Although small retail activities still constitute the largest share of business, in recent years, there has been increasing interest in service provision (see Figure 2).

Within the retail category, traditional sectors such as wholesaling (14\%), daily food retail or convenience stores (8\%), construction and related sectors (up to 7\%), textiles, restaurants and bakeries (each 5-6\%) remain dominant. In the database, however, we encountered a number of new services and products that require more sophisticated skills, such as accountancy, security system services, computer and electronic services, do-it-yourself chains, insurance and consultancy services, organizational and entertainment-related services and camping products. Although these remain scarce, their existence points to a new trend in sector and product choice among ethnic entrepreneurs. Moreover, during interviews with these "special" businesses, we were able to understand more about their owners' motives and approaches.

In addition to the sectoral typology, we classified businesses in terms of their clientele. We identified four main categories:

(1) Businesses related to ethnic origin and serving the ethnic community. These businesses provide ethnic products and services to religious and ethnic groups. Examples include community services, teahouses, Turkish associations and so forth. 


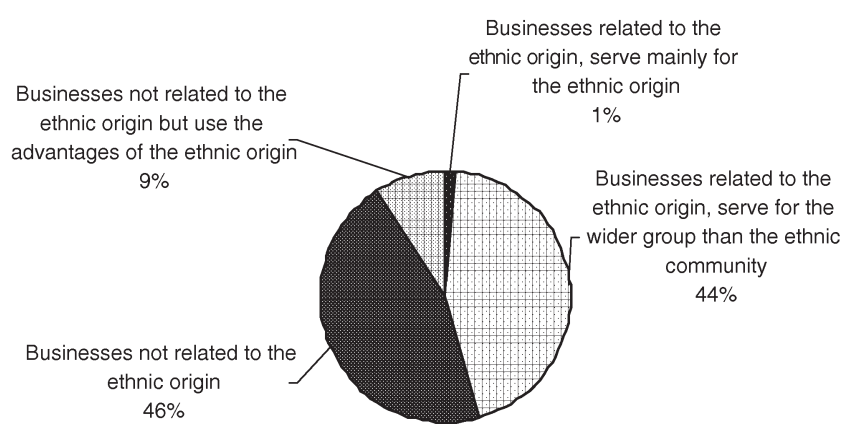

Figure 3. Businesses and ethnic origins, Antwerp Source: Fieldwork.

(2) Businesses related to ethnic origin but serving a wider public. These businesses sell ethnic products and services in combination with non-ethnic products and services. Examples include Turkish restaurants, Turkish food retail shops, Turkish non-food retail shops, bakeries and so forth.

(3) Businesses not related to ethnic origin. These businesses do not sell ethnic products and services, and do not specifically aim at a Turkish clientele. Examples include contractors, hardware/building suppliers, tailors and hairdressers.

(4) Businesses not related to ethnic origin but which capitalize on ethnic origin, including skills and networks. Examples would include Italian restaurants, cleaning companies and so forth.

The proportion of Antwerp businesses in each of these categories is shown in Figure 3 (the figures are drawn from the KBO database).

According to these figures, Turkish businesses in Antwerp are predominantly either unrelated to ethnic origin (46\%), or related to ethnic origin but serving a wider clientele (44\%). This is an interesting outcome, suggesting a shift towards success and competition in the market via the selection of non-ethnic businesses and services. Such a shift would clearly increase levels of interaction between diverse groups.

\subsection{Different Immigrant Education and Skills Levels and their Role in the Labour Market of a Growing Economy}

Immigrants with differing education and skill levels contribute to a city's competitiveness in two ways. First, the development of new industries that draw upon skilled labour and second, the expansion of traditional activities and mature manufacturing sectors enable a city to increase its export capacity and provide new employment opportunities. It is increasingly evident that due to the pressures of globalization, changing economic conditions are forcing cities to define new ways to become competitive-such as strategies grounded in labour market characteristics.

Immigrants arriving in Izmir from the various regions have different levels of education and employment prospects. The literature puts strong emphasis on the importance of knowledge, skills and innovative capacity—in other words, human capital—for the development of cities and regions, and there is almost consensus on the adaptability of a 
highly skilled workforce to the conditions imposed by globalization (Pinelli et. al., 1995; Kresl, 1995; Lever \& Turok, 1999). Our study of Izmir provides more evidence to support these hypotheses. There are more households with university-level education that are employed as administrative and technical managers or in technical and personnelrelated fields, and who have improved their relative incomes and standard of living, than those new migrant groups with limited education who have experienced income deprivation. In fact, the statistical analysis indicates a significant difference in the direction of change of income among households with different levels of education and occupation (Eraydin, 2008a).

The field survey findings indicate significant differences between the education levels of migrants from different parts of Turkey and Izmir (see Table 4). While the proportion of highly-educated immigrants is lower in the case of the least-developed regions, interestingly, the shares of immigrant among the groups from other regions are relatively higher. This would suggest that Izmir is attracting highly-educated people, as well as unskilled workers, which may be helping to make the city increasingly competitive. In fact, this is a new phenomenon in Turkey, suggesting that migrants can be a new source of high economic performance for major metropolitan areas.

Differences in levels of education are reflected in the types of employment taken by different migrant groups. The proportion of employees in white- and blue-collar jobs differs significantly per immigrant group. As Table 4 clearly indicates, immigrants from high-income regions and from abroad tend to take white-collar jobs, whereas immigrants from medium- to low-income regions tend to be employed in blue-collar jobs.

Table 4. Share of active population with high levels of education and distribution of population by job type (Izmir)

\begin{tabular}{lccc}
\hline & $\begin{array}{c}\text { Share of active population } \\
\text { with university education } \\
(\%)\end{array}$ & $\begin{array}{c}\text { Share employed in } \\
\text { white-collar jobs } \\
(\%)\end{array}$ & $\begin{array}{c}\text { Share employed in } \\
\text { blue-collar jobs (\%) }\end{array}$ \\
\hline $\begin{array}{l}\text { Izmir-born } \\
\begin{array}{c}\text { Migrants from Izmir and } \\
\text { the surrounding } \\
\text { regions }\end{array}\end{array}$ & 16.4 & 57.6 & 42.4 \\
$\begin{array}{c}\text { Migrants from high- } \\
\text { income regions }\end{array}$ & 15.0 & 40.6 & 59.4 \\
$\begin{array}{c}\text { Migrants from medium- } \\
\text { income regions }{ }^{\mathrm{d}}\end{array}$ & 28.6 & 67.6 & 32.4 \\
$\begin{array}{c}\text { Migrants from least- } \\
\text { developed regions }\end{array}$ & 19.8 & 38.0 & 62.0 \\
Migrants from abroad & 12.7 & 27.5 & 72.5 \\
\hline
\end{tabular}

${ }^{\mathrm{a}}$ The term white-collar worker refers to a salaried professional or an educated worker who performs semiprofessional office, administrative and sales coordination tasks, as opposed to a blue-collar worker, whose job requires manual labor. "White-collar work" is an informal term, defined in contrast to "blue-collar work".

${ }^{\mathrm{b}} \mathrm{TR} 3$ Aegean.

${ }^{\mathrm{c}}$ TR1 Istanbul, TR2 Western Marmara, TR4 Eastern Marmara, TR5 Western Anatolia.

${ }^{\mathrm{d}}$ TR6 Mediterranean, TR7 Middle Anatolia, TR8 Western Black Sea, TR9 Eastern Black Sea.

'TRA Northeast Anatolia, TRB Mid-Eastern Anatolia, TRC Southeast Anatolia.

Source: Interviews, field survey, June-July 2007. 
As Table 4 emphasizes, there is a considerable difference in education levels between migrants and Turks born in Izmir. Although, as suggested earlier, the theoretical literature on competitiveness emphasizes the importance of human capital for integrating into a global economy; competitiveness via human capital is only one type of integration. As Eraydin (2008b) suggests, there are a number of ways to integrate into the global economy, one of which is integration aided by the use of cheap labour in mature production sectors. Having such a diverse population allows Izmir to adapt flexibly to conditions in the volatile global market. Its migrants, meanwhile, create their own social support mechanisms and social networks, and benefit from social capital, enabling them to integrate into the metropolitan economy and survive in the face of change. In the Izmir case, having a relatively cheap labour pool, consisting mainly of immigrants from less-developed regions of Turkey, is an important asset.

Izmir's ability to attract both skilled and unskilled migrants from several countries, as well as from different parts of Turkey, gives the city an advantage when it comes to coping with changing economic conditions. A supply of qualified labour, in the form of scientific and technical personnel from other Turkish regions, makes the city attractive to new enterprises. The number of people working in the "scientific and technical personnel" category, for example, rose from 77,300 in 1990 to 116,700 in 2000 (4.2\% annual increase). On the other hand, the migration of less-skilled workers caused wage levels for unskilled jobs to remain relatively low, enabling a number of firms in mature production sectors to sustain a comparative advantage.

The city's competitiveness, which has been bolstered by the labour market conditions described earlier, allowed for a sustained increase in exports. This, in turn, drew upon the city's existing manufacturing capacity, which was mainly based in labour-intensive mature production sectors. Traditional production sectors obviously tend to offer lowwage jobs, which would imply the importance of survival strategies for people employed in such industries, and the key role played by social support mechanisms and social capital in enabling them to adapt to new conditions. In recent years, however, Izmir has increasingly been exporting higher-value products, aided by increasing innovation particularly in manufacturing industries. Between 1989 and 2001, for instance, the value of exports from Izmir's manufacturing sector tripled. ${ }^{6}$

\subsection{Informal Support Mechanisms: Survival and Relationships in Host Societies}

As suggested earlier, the literature emphasizes the importance of social capital and patterns of social interaction for urban and regional competitiveness. Social capital is particularly vital for immigrants, as a means of both surviving in and integrating into a recipient society.

Our findings show that in both cities, people's families play a key role in their capacity to initiate new business, which is very important in the economic performance of the cities. The findings demonstrate that although there may be differences in income and social status among groups, family remains the most important factor enabling people to adapt to new conditions, or at the very least, to survive. Immigrant households do not depend upon formal institutions, which are too weak to sustain them. Moreover, they lack confidence in existing social institutions.

In the case of Antwerp, where Turkish immigrants have developed networks, a sense of identity, and retain a strong degree of social control, there is clear evidence of the 
importance of kinship relations in business. We can thus say that bonding and bridging capital are dominant in this respect. Even though advanced financial support mechanisms are available to small entrepreneurs, Turkish immigrants appear to prefer family support to other financial instruments (such as bank credit, loans and entrepreneurship funds). Most of the informants, who received the family support, indicated that it was much easier and less complex to ask a family member than applying for the bank credits due to the complexity of the procedure (especially due to the language barrier). Although linking capital is not as dominant as the bonding or bridging capital, with the Flemish-speaking second generation, linking capital is expected to increase in the future.

Recourse to external financing remains rare among Turkish entrepreneurs. During the in-depth interviews, $72 \%$ of interviewees indicated that they had not used external financing to establish their businesses. Of those who had received financial support, $61 \%$ had been assisted by family and friends. This highlights the importance of bonding capital for Turkish immigrants. Moreover, during our interviews, we frequently heard comments such as, "I owe everything to my family's support", "my business partner and I got all the help we needed from our friends", "thanks to good friends, money was not an issue" and "friends of mine suggested that I start this business, as they noticed a need for it". Social networking is still one of the Turkish business community's strongest assets, although a number of entrepreneurs are proud of their growing independence.

The involvement of family and friends in the decision-making and financing of a business is an important indicator of the role of networks. Our interviews indicate that $50 \%$ of entrepreneurs took crucial business decisions-relating to a product, location or strategy, for example-aided by friends and family (regardless of whether the amount of help was great or small). One of the interviewees pointed out that "people do not go to the bank to borrow money because they do not know how to organize it, mainly because they do not speak the language. So the easiest way is to turn to your own network to raise funds". Younger generations make greater use of bank credit than older ones, however.

In a similar way, the results of the Izmir study demonstrate that social capital is grounded in connectedness and interactions with one's family members, the phenomenon that is termed "bonding capital" in the literature (Table 5). More than $70 \%$ of Izmir-born and other immigrant groups declared that different kinds of relationships with family members had been an important factor in their ability to adapt to changing economic conditions. Around 20\% indicated that bridging capital (interactions with neighbours and friends) had been important, with little differentiation for immigrants with different characteristics. Less than $10 \%$ of the immigrants surveyed suggested that "linking" social capital had played an important role in their adaptation and improvement of living conditions. One significant finding is that the importance of interactions with fellow citizens has decreased. This was particularly critical for immigrants arriving during the early waves of migration, in the 1960s and 1970s. Nineteen have the lowest frequency of contacts. It shows the decreasing importance of having the same cultural background.

What are the main factors motivating these social relations? Our findings show that motivation differs across diverse migrant groups. Most existing relations are seen as being for socialization purposes and for participating in social activities. Relatives, 
Table 5. The role played by relatives, friends and neighbours, for immigrants from different regions (Izmir)

\begin{tabular}{lcccr}
\hline & $\begin{array}{c}\text { Financial } \\
\text { support }\end{array}$ & $\begin{array}{c}\text { Social } \\
\text { support }\end{array}$ & $\begin{array}{c}\text { Social } \\
\text { interaction }\end{array}$ & Other \\
\hline Izmir-born $^{\text {Migrants from Izmir and surrounding regions }}{ }^{\mathrm{a}}$ & 10.3 & 17.5 & 67.9 & 4.3 \\
Migrants from high-income regions $^{\mathrm{b}}$ & 13.5 & 10.0 & 71.5 & 5.0 \\
Migrants from medium-income regions $^{\mathrm{c}}$ & 11.8 & 20.5 & 55.9 & 11.8 \\
Migrants from least-developed regions $^{\mathrm{d}}$ & 14.0 & 18.0 & 60.0 & 8.0 \\
Migrants from abroad $^{\text {Total }(\%)}$ & 18.2 & 27.2 & 54.6 & 0.0 \\
& 10.0 & 26.7 & 63.3 & 0.0 \\
\hline
\end{tabular}

${ }^{\mathrm{a} T R 3}$ Aegean.

bTR1 Istanbul, TR2 Western Marmara, TR4 Eastern Marmara, TR5 Western Anatolia.

${ }^{\mathrm{c}}$ TR6 Mediterranean, TR7 Middle Anatolia, TR8 Western Black Sea, TR9 Eastern Black Sea.

${ }^{\mathrm{d}}$ TRA Northeast Anatolia, TRB mid-Eastern Anatolia, TRC Southeast Anatolia.

Source: Interviews, field survey, June-July 2007.

friends and neighbours do provide social and financial support whenever needed, however. It is interesting to note that approximately one-third of relationships are constructed upon expectations of support. This indicates that for each immigrant group, social relations still offer not only a means of survival, but also adaptation in the face of unexpected changes. Financial support obviously plays a more important role for immigrants from the leastdeveloped regions.

The findings summarized earlier indicate that bonding capital plays a critical role for immigrants and their adaptation to the new economic conditions and to initiate new enterprises. For almost every group, levels of trust and reciprocity are higher for family-based relationships-even more so than bridging and linking capital. However, the findings indicate a tendency to develop bridging capital by participating in social activities, suggesting that relationships with friends and neighbours are an important means of socialization. In terms of linking capital, the findings indicate that immigrants are less likely to interact with formal institutions than with informal ones.

\section{Conclusion}

The findings of our two case studies reveal that different kinds of diversity play an important role in urban economic performance. In this respect, entrepreneurs, skilled migrants and unskilled labour have important roles to play. Immigrants contribute to the growth of different forms of production and services, not only as a result of their talents and skills, but also as a result of their social connections. Social capital enables immigrants to survive in a recipient country, and integrate into an economy without excessive reliance on formal institutions.

Immigrants depend on social capital to facilitate their integration into local labour markets, and to become active agents in a local economy. Attempting to adapt to changing conditions in the volatile global economy, they can fill the gaps in an economy and engage in low-wage jobs (as is the case in Izmir), or they can also become entrepreneurs. Immigrants draw upon their strong connections with families and friends to adapt to 
changing conditions, which is the most important issue of the cities looking for in the contemporary economic conditions.

While they contribute to the economic performance of the recipient urban economies, they undoubtedly face significant problems, which also indicates the burden they have to pay in this process. While some immigrants manage to scale the social capital ladder, achieving higher levels of education and gaining access to better employment opportunities, some disadvantaged groups, who do not adjust to their new social, cultural and economic realities, fail to access any of the opportunities mentioned earlier. What happens to such groups in both cities during the integration process?

If one focuses on these groups, one sees a very different picture from that of increasing entrepreneurship, social integration and urban competitiveness: one of extremely high unemployment, and increasing numbers of immigrants living below the poverty line. In Belgium, it has been claimed that at least $58.9 \%$ of Turks and $55.6 \%$ of Moroccans are living below the poverty line. ${ }^{7}$ This, of course, has a direct impact on the crime motives of these groups. However, compared with those of the Turkish youngsters, who has strong social control, networking and community behaviour, the crime rates among young Moroccans is higher due to lose social ties. During our research in Antwerp, we observed two interlinked and contradictory processes. First, unemployment is increasing among immigrant groups (in 2008, for instance, $28 \%$ of the total number of unemployed were of non-EU origin, according to Databank Sociale Planning), and poverty was particularly evident among women and disadvantaged groups. Second, it would appear that the high level of unemployment is not simply a matter of lacking access to job opportunities. Rather, especially for young male immigrants, it is a question of lacking interest in work. Our interviewees claimed that the relatively generous social benefits provided by the Flemish Government have the effect of undermining young people's motivation to find jobs. It is, however, quite difficult to gather information about people's real experiences of poverty, and further research on this issue is needed.

In Izmir, meanwhile, two issues have become particularly important for immigrants over the last two decades: first, how immigrants' incomes and living conditions have changed; and second, the extent to which they have preserved connections with relatives and formed new relationships with the rest of society.

According to our survey, some of the migrant groups have been able to improve their incomes and living conditions. Others, however, report that their living conditions have worsened. Our detailed analysis shows that with the exception of immigrants from abroad, a smaller proportion of immigrants were able to better their living conditions and incomes than compared with Izmir-born Turks. Among those immigrants who were not successful in coping with changing economic conditions, of those workers whose living conditions and incomes had worsened, $40 \%$ had migrated from lessdeveloped regions. Obviously, this is not simply a question of immigrants integrating into the local economy, but a more general problem affecting the locality; a need for more skills and education, combined with than cultural differences, lies at the root of this.

Second, our findings relating to the importance of bonding capital provide clues as to what creates the sense that households belong to, and are connected with, their immediate social environments. The high density of family relationships indicates the important role played by social relationships in sustaining households in a big city. Maintaining such a limited sphere of social interaction brings the risk of deeply repressive social control 
mechanisms, however, and promises little scope for individual autonomy. A family-based social support system can act as a mechanism for controlling the reactions of social groups, and can make society more conservative. The development of such structures prompts a number of important questions about the future of such societies. Indeed, the competitiveness literature should pay more attention to the issue of interaction among different groups, since the very fact of such interaction is an argument in favour of diversity and multiculturalism.

In our view, in order to profit from multiculturalism's positive aspects, local and national governments should invest further in increasing capacity for social capital. In doing so, governments should develop more integrated social, economic and spatial policy initiatives that are specifically designed to serve diverse groups. Alongside preventative policies that are intended to counter its disadvantages, these initiatives should allow for the fact that such groups can contribute to society and the economy in different ways. Celebrating diversity does not mean compounding the socio-spatial and economic problems faced by immigrants. Rather, it means identifying new policies to facilitate participation by immigrants with different cultural backgrounds in the economy, so as to stimulate innovation and competition.

\section{Notes}

1. Within the framework of this paper, we define migrants as people who came to a country, or to another region in the same country where they were not born in order to settle.

2. The telephone interview questions (originally asked in Turkish) are:

Name of the business:

Address:

Name of the owner:

Type of business/trade/service:

Nationality and birth place of the owner:

When did you establish this business?

Is this your first business?

Yes/no

If no

What was the previous business type?

If different from the current one:

Why changed the type of business?

Why changed the product?

Why did you chose this line of business?

What/who was influential in your selection of this line of business?

Why did you chose this very location?

Who/what influenced this decision?

If it is not the first business:

Was the location of your previous business in this neighbourhood as well?

If different location:

Why different location?

Did you get financial support while establishing your business?

If so what was the source of this support?

3. The 496 questionnaire forms were distributed across eight neighbourhoods ( 62 per neighbourhood). The distribution of questionnaires was not based upon ratios, but on a hypothetical distribution. According to category of each neighbourhood in a homogenous structure $(p=0.2 / q=0.8), 496$ questionnaires enabled us to achieve a $95 \%$ confidence level.

4. By special arrangement, Greeks living in Istanbul and Turks living in the Greek part of Thrace were exempted from the compulsory exchanges. 
5. The income per capita of the regions in 2001 (TUIK-Turkish Statistical Institute data, 2009).

\begin{tabular}{llc}
\hline Code & \multicolumn{1}{c}{ Region } & GDP per capita (\$) \\
\hline TR1 & Istanbul & 3063 \\
TR2 & Western Marmara & 2399 \\
TR3 & Aegean & 2545 \\
TR4 & Eastern Marmara & 3268 \\
TR5 & Western Anatolia & 2313 \\
TR6 & Mediterranean & 2041 \\
TR7 & Inner Anatolia & 1582 \\
TR8 & Western Black Sea & 1707 \\
TR9 & Eastern Black Sea & 1428 \\
TRA & Northeastern Anatolia & 919 \\
TRB & Mid-Eastern Anatolia & 1071 \\
TRC & Southeastern Anatolia & 1186 \\
\hline
\end{tabular}

6. From 1.7 billion US dollars to 4.9 billion US dollars.

7. In practice, the main measure of poverty used in the EU at present is the Eurostat definition: the percentage of people with an income of $60 \%$ or less of the median income in the country in which they live (ref: http://ec.europa.eu/regional_policy/sources/docoffic/official/reports/p122_en.htm\#1).

\section{References}

Amin, A. \& Graham, S. (1997) The ordinary city, Transactions of the Institute of British Geographers, 22(4), pp. 411-429.

Barett, G. A., Jones, T. P. \& Mcevoy, D. (2001) Socio-economi and policy dimensions of the mixed embeddedness of ethnic minority business in Britain, Journal of Ethnic and Migration Studies, 27(2), pp. 241-258 (Special issue on "Immigrant Entrepreneurship" edited by R. Kloosterman \& J. Rath).

Beneria, L. \& Roldan, M. (1987) The Crossroads of Class and Gender: Industrial Homework, Subcontracting and Household Dynamics in Mexico City (Chicago, IL: University of Chicago Press).

Benton, L. A. (1990) Invisible Factories: The Informal Economy and Industrial Development in Spain (Albany, NY: The University of New York Press).

Bodaar, A. \& Rath, J. (2005) Cities, diversity and public space, Metropolis World Bulletin, 5(September), pp. 3-5.

Bourdieu, P. \& Wacquant, L. J. D. (1992) An Invitation to Reflexive Sociology (Chicago, IL: University of Chicago Press).

Chant, S. \& McIlwaine, C. (1995) Gender and export manufacturing in the Philippines: Continuity and change in female employment? The case of the Mactan export processing zone, Gender, Place and Culture, 2(2), pp. 147-176.

Eraydin, A. (2008a) The conditional nature of relations between competitiveness, social cohesion and spatial inequalities: The evidence from Istanbul, in: P. Ache, H. T. Andersen, T. Moulatas, M. Raco \& T. Tasan-Kok (Eds) Reconciling Competitiveness and Social Cohesion: Theories and Facts (Dordrecht: Springer).

Eraydin, A. (2008b) The impact of globalisation on different social groups: Competitiveness, social cohesion and spatial segregation in Istanbul, Urban Studies, 45(8), pp. 1663-1691.

Eraydin, A. \& Erendil, A. (1999) Yeni Üretim Süreçleri ve Kadın Emegi (Ankara: Başbakanlık).

Fainstein, S. (2005) Cities and diversity: Should we want it? Can we plan for it? Urban Affairs Review, 41(1), pp. 3-19.

Florida, R. (2001) The Rise of the Creative Class: And How It's Transforming Work, Leisure, Community and Everyday Life (New York: Basic Books).

Florida, R. (2005) Cities and the Creative Class (New York: Routledge).

Foord, J. \& Ginsburg, N. (2004) Whose hidden assets? Inner city potential for social cohesion and economic competitiveness, in: M. Boddy \& M. Parkinson (Eds) City Matters: Competitiveness, Cohesion and Urban Governance (Bristol: Policy Press).

Forrest, R. \& Kearns, A. (2001) Social cohesion, social capital and the neighborhood, Urban Studies, 38(12), pp. 2125-2143. 
Gerometta, J., Häussermann, H. \& Longo, G. (2005) Social innovation and civil society in urban governance: Strategies for an inclusive city, Urban Studies, 42(11), pp. 2007-2021.

Gonzáles, S. \& Healey, P. (2005) A sociological institutionalist approach to the study of innovation in governance capacity, Urban Studies, 42(11), pp. 2055-2069.

Hirschon, R. (2003) Crossing the Aegean: An Appraisal of the 1923 Compulsory Population Exchange Between Greece and Turkey (New York: Berghahn Books).

Kesteloot, C., De Decker, P. \& Manco, A. (1997) Turks and housing in Belgium, with special reference to Brussels, Ghent and Vise, in: S. Ozuekren \& R. Van Kempen (Eds) Turks in European Cities: Housing and Urban Segregation (Utrecht: Ercomer).

Kleinhans, R., Priemus, H. \& Engbersen, G. (2007) Understanding social capital in recently restructured urban neighbourhoods: two case studies in Rotterdam, Urban Studies, 44(5-6), pp. 1069-1091.

Kloosterman, R. \& Van der Leun, J. P. (1999) Just for starters: Commercial gentrification by immigrant entrepreneurs in Amsterdam and Rotterdam Neighbourhoods, Housing Studies, 14(5), pp. 659-677.

Kloosterman, R. \& Rath, J. (2001) Immigrant entrepreneurs in advanced economies: Mixed embeddedness further explored, Journal of Ethnic and Migration Studies, 27(2), pp. 189-202.

Kresl, P. K. (1995) The determinants of urban competitiveness: A survey, in: G. Gappert \& P. K. Kresl (Eds) North American Cities and The Global Economy, pp. 45-68 (Thousand Oaks, CA: Sage).

Kunzmann, K. (2005) Creativity in planning: A fuzzy concept? DiSP, 162(3), pp. 5-13.

Landry, C. (2000) The Creative City: A Toolkit for Urban Innovators (New York: Earthscan).

Lever, W. F. \& Turok, I. (1999) Competitive cities: Introduction to review, Urban Studies, 36(5-6), pp. 791-793.

Maloutas, T., Raco, M. \& Tasan-Kok, T. (2008) Conclusions competitiveness and cohesion: One discourse, multiple realities and new challenges for policy and research, in: P. Ache, H. T. Andersen, T. Moulatas, M. Raco \& T. Tasan-Kok (Eds) Cities between Competitiveness and Cohesion: Discourses, Realities and Implementation, pp. 259-275 (Dordrecht: Springer).

Mumford, M. D. (2002) Social innovation: Ten cases from Benjamin Franklin, Creativity Research Journal, $14(2)$, pp. 253-266.

Nijkamp, P. (2003) Entrepreneurship in a modern network economy, Regional Studies, 37(4), pp. 305-405.

Peck, J. (1996) Work Place: The Social Regulation of Labour Markets (New York: The Guilford Press).

Pichler, F. \& Wallace, C. (2007) Patterns of formal and informal social capital in Europe, European Sociological Review, 23(4), pp. 435-423, DOI:10.1093/esr/jcm013.

Pinelli, D., Giacometti, R., Lewney, R. \& Fingleton, B. (1995) European Regional Competitiveness Indicators, Discussion Paper 103, Department of Land Economy University of Cambridge. Available at http://www. Landecon.cam.ac.uk (accessed 15 May 2008).

Portes, A. (1998) Social capital: its origins and applications in modern sociology, Annual Review of Sociology, 24, pp. $1-24$.

Portes, A. \& Landolt, P. (1996) The downside of social capital, The American Prospect, 26, pp. 18-23.

Portes, A. \& Sensenberger, J. (1993) Embeddedness and immigration: Notes on the social determinants of economic action, The American Journal of Sociology, 98(6), pp. 1320-1350.

Ratcliffe, P. (Ed.) (2001) The Politics of Social Science Research. "Race" Ethnicity and Social Change (Basingstoke, UK: Palgrave).

Rath, J. (2000) Immigrant Businesses: The Economic, Political and Social Environment (London: Macmillan Press Ltd).

Rath, J. (2001) Research on immigrant ethnic minorities in the Netherlands, in: P. Ratcliffe (Ed.) The Politics of Social Science Research. "Race" Ethnicity and Social Change (Basingstoke, UK: Palgrave).

Sandercock, L. (2003) Cosmopolis II: Mongrel Cities of the 21st Century (London: Continuum).

Storper, M. (1997) The Regional World: Territorial Development in a Global Economy (New York: Guilford Press).

Tasan-Kok, T. \& Vranken, J. (2008) From survival to competition? The socio-spatial evolution of Turkish immigrant entrepreneurs in Antwerp, in: P. Ache, H. T. Andersen, T. Moulatas, M. Raco \& T. Tasan-Kok (Eds) Cities Between Competitiveness and Cohesion: Discourses, Realities and Implementation, pp. 151-169 (Dordrecht: Springer).

Thrift, N. \& Olds, K. (1996) Reconfiguring the economic in economic geography, Progress in Human Geography, 20(3), pp. 311-337.

Turok, I. \& Bailey, N. (2004) Twin track cities? Competitiveness and cohesion in Glasgow and Edinburgh, Progress in Planning, 62(3), pp. 135-204. 
Turok, I. (2005) Social cohesion as a factor of competitiveness and regional growth, Unpublished paper presented at OECD International Conference "Sustainable Cities: Linking Competitiveness with Social Cohesion", October 13-14, Montreal.

Uitermark, J., Rossi, U. \& Van Houtum, H. (2005) Reinventing multiculturalism: Urban citizenship and negotiation of ethnic diversity in Amsterdam, International Journal of Urban and Regional Research, 29(3), pp. 622-640.

Waldinger, R. (1997) Social Capital or Social Closure? Immigrant Networks in the Labor Market, Working Paper 26, Los Angeles, CA: The Lewis Center for Regional Studies, UCLA School of Public Policy and Social Research.

Waldinger, R., Aldrich, H., Ward, R. \& Stanfield, J. H. (1990) Ethnic Entrepreneurs: Immigrant Business in Industrial Societies, Sage Series on Race and Ethnic Relations, Vol. 1 (Newbruy Park: Sage Publications).

Wall, E., Ferazzi, G. \& Schryer, F. (1998) Getting the goods on social capital, Rural Sociology, 63(2), pp. 300-322.

Zachary, P. (2000) The Global Me: New Cosmopolitans and the Competitive Edge: Picking Globalism's Winners and Losers (New York: Public Affairs). 